\title{
Cambio social en clave de comunicación'
}

\author{
ISABEL Soto MAYEdo \\ Agencia Prensa Latina
}

"Sólo siendo juntos seremos capaces de descubrir lo que podemos ser, contra una tradición que nos ha amaestrado para el miedo y la resignación y la soledad y que cada día nos enseña a desquerernos, a escupir al espejo, a copiar en lugar de crear"

\section{1-El poder de los medios en el siglo XXI}

a dictadura mediática nos somete. Por más resistencia que hacemos, a veces terminamos sucumbiendo frente a una que otra propuesta de la pertinaz lluvia de supercherías bien pensadas por los encargados de oxigenar al capitalismo a partir del fomento de una cultura de masas, acorde con los postulados de dominación de ese sistema.

Las sutilezas escasean. El mensaje discriminador es cada vez más descarnado y a tono con ello, pronto se aprende que para alcanzar el probable triunfo anunciado vale salir de compras con mayor frecuencia, aclararse el cabello, depilarse el cuerpo y la mente, y someterse a la tiranía de un régimen alimenticio estresante.
Las trasnacionales mediáticas y sus repetidoras nacionales aumentan sus dividendos con el manejo de poderosas armas: la información, la publicidad y el entretenimiento. La combinación de estas les permite imponer estilos de vida e intereses, el individualismo, el consumismo, la pérdida de identidad, y la dependencia en todos los órdenes.

Los códigos inoculados por los megamedios y sus sucedáneas incitan a mujeres y hombres a dedicar más tiempo al cuidado de la apariencia, que a pensar. Simplificar parece ser la fórmula mágica. La relativización de las posiciones políticas, económicas y en general; la ambigüedad de los personajes $y$ situaciones relatadas; la superficialidad al representar el entramado 
social y a los actores- receptores de los mensajes, procuran frenar la tendencia humana a tratar de entender lo que acontece y en particular, cómo el pasado incide en el hoy. Esa no es cuestión que deba preocupar, sugieren en clave subliminal los agentes de la difusión.

En esta era de monopolios mediáticos preestablecidos, respetuosos de los preceptos más turbios de la concepción nacionalsocialista alemana acerca de la propaganda, la rigurosa jerarquía impuesta mantiene sólo a ciertas televisoras y periódicos como referentes de la información circulante por el mundo, quienes exhiben sin recato el traje de soldados e indispensables engranajes de la organización y ejecución de planes dirigidos a avasallar voluntades ${ }^{3}$.

Los encargados de promover o justificar guerras, alientan la desmoralización, el olvido y la ignorancia. Lejos de promover la educación cívica y arrojar luces sobre lo que acontece en cualquier parte, metamorfosean la realidad según los intereses de sus patrocinadores e incentivan la degradación ambiental, el despilfarro, el consumismo, y la violencia.

En vez de cubrir el déficit de identidad ascendente en nuestras sociedades occidentalizadas -por la quebradura de pilares básicos como la familia, la Iglesia Católica y otras instituciones-, los predestinados a formar opinión pública tratan a los seres humanos como vil mercancía.

\section{- Mercantilización mediática}

El respeto a las leyes de la información hace mucho cedió el terreno a la producción de noticias bajo las leyes de la oferta y la demanda. Hasta los mejores intencionados, adaptan sus formas de decir y hacer, con el propósito de insertarse en el mercado y vender mejor.

En ese esfuerzo, los medios de difusión masiva ${ }^{4}$ siguen las leyes de la retórica y otras dominantes en la cultura de masas. Prevalecen los efectos de emisión, simplicidad, espectacularidad, maniqueísmo, velocidad, urgencia, e instantaneidad, en el sentido de la velocidad en tiempo real.

Gracias a la magia de Internet, espacio es un concepto pasado de moda para las comunicaciones en este siglo. La noción del tiempo real, llevada a al mundo de la información, destruyó la obediencia al período necesario para elaborar las noticias y destapó la premura por transmitir, en el orden técnico meramente, en desmedro de la verificación oportuna de datos y de la calidad del producto comunicativo en general.

El valor de la información ahora descansa en la agilidad con que llegue a los receptores, luego de ocurrir el hecho noticioso, y el de 
los medios de difusión masiva, en su capacidad de competir por llegar primero a vender.

La gratuidad en los servicios de esta naturaleza, cultura impulsada también por la red de redes, perturba a su vez los mecanismos comerciales de la información. Los gratuitos crecen, en la misma medida en que otra vía se impone para captar el beneficio económico por los mensajes. "El negocio consiste en vender ciudadanos a los anunciantes", lo define el Doctor en Semiología e Historia de la Cultura, Ignacio Ramonet ${ }^{5}$.

Los vendedores de productos comunicativos batallan por atrapar a más receptores en esta época y recibir, en proporción, más solicitudes de campos para publicidad. Para ello, la información tiene que bajar su nivel de elaboración, reajustarse para atrapar al menos interesado en consumirla. Cuantos más atrayente y sencilla sea esta, más numerosos serán los que se le acerquen y el medio ganará más interesados en publicar sus anuncios en él.

Tantos leen, escuchan o miran un medio, tantos pueden ser capturados por los promotores de los bienes de la sociedad de consumo y la urgencia en modificar el funcionamiento estructural de la información, para lograrlo, redunda en el descuido de parámetros esenciales como la verdad, siempre subjetiva y en función del punto de vista de quien la transmite.
La globalización neoliberal, impensable sin el progreso desmesurado de las comunicaciones en su arista tecnológica, modificó todas las estructuras de funcionamiento de la sociedad. Este fenómeno, esencialmente económico, implicó el aniquilamiento de las barreras a la circulación de los capitales, al desmaterializar el mercado de cambio. En este contexto, los medios dejaron atrás su insistencia en preservarse como el Cuarto Poder ${ }^{6}$ y reacomodaron sus expectativas.

La revolución digital, hija de un proyecto encaminado a agilizar el trasiego de capitales y no a proporcionarnos el placer del amor o la amistad a despecho de distancias físicas, creó un sexto continente: Internet. Este impulsó la fusión de las empresas especializadas en materia comunicativa e informática.

Texto, imagen y sonido, andan tomados de la mano por las autopistas del ciberespacio, mientras se fortalecen los pulpos integradores de las principales esferas de la información. La rentabilidad es la única preocupación de las megaempresas telefónicas, informáticas, y comunicativas.

Los medios, convertidos en actores dominantes en sociedad a partir de su matrimonio con el poder financiero, no se conforman con relativizar la fuerza de los otros poderes y asumen el papel de aparatos ideológicos de la globalización. De 
acuerdo con Ramonet, esta penetra con el apoyo del ahora Segundo Poder-detrás del financiero y por delante del político-, que la estableció y defiende como sinónimo de progreso o modernidad.

Aparejada a esta idea, corre una orientada a inmovilizar cualquier síntoma de resistencia, sustentada en la tesis de la imposibilidad de luchar contra la pareja infernal que suponen los medios y el poder financiero.

La voluntad política de supeditar a ambos es un arma temida por los adalides del sostenimiento de la ideología globalizadora. No es gratuito que esta expresión de resistencia a la intensión de dominar el mundo sea la más atacada por el aparato mediático en el siglo XXI. De ello dan fe las múltiples maquinaciones contra el gobierno de la República Bolivariana de Venezuela y su líder Hugo Chávez; el presidente ecuatoriano Rafael Correa; su par boliviano Evo Morales y sus homólogos Cristina Fernández (Argentina) y Daniel Ortega (Nicaragua), por sólo citar algunos.

\section{- Incomunicación como estrategia de dominación}

Las dictaduras militares diseminadas por América Latina en los años ochenta y los sucesivos descalabros de sistemas políticos orientados al socialismo, entre otros factores, permitieron al aparato mediático cultivar un imaginario derrotista en relación con las revoluciones, sacudir a las utopías, y reforzar la cultura del mercado. Las nociones predicadas por la modernidad adelantaron camino a sus anchas en medio de este escenario subjetivo y muchos aceptaron de manera acrítica la devaluación de ideologías, de proyectos políticos transformadores, de las pasiones encarnadas por estos, de las prácticas sociales colectivas, y de los sentimientos y valores humanos considerados trascendentes.

El "vale todo" plantó sus botas sobre las culturas locales y trocó todo en descartable y efímero, con el respaldo de una discursiva mediática potenciadora de la desfragmentación y el desprecio a las prácticas anticapitalistas conscientes o simbólicas ${ }^{7}$.

Los avances tecnológicos, en tanto favorecieron la globalización del conocimiento de lo que sucede en los lugares más remotos, favorecieron la conformación de la subjetividad de esta época histórica, la saturación informativa y la incomunicación alienante.

La enajenación de los sujetos se puso a la orden del día como consecuencia del distanciamiento creado por la política hegemónica, entre las imágenes y dichos que saturan los medios -para sembrar en los receptores una percepción del mundo funcional a su proyecto de 
dominación- y el ancho campo de las resistencias, los dolores y las esperanzas populares. Ello redundó en el desencuentro entre las palabras y sus significados y de las imágenes que consumimos con las representaciones de nuestros actos cotidianos.

La "comunicación en formato zapping" agudiza la comprensión de las relaciones causa- efecto y en consecuencia, del papel protagónico de las masas populares o sujetos colectivos en la historia. Ello explica en buena parte la proliferación de interpretaciones mesiánicas, de fundamentalismos, la exacerbación de los individualismos, y la continua frustración de la creencia en los fetiches sucesivos establecidos por el mercado $^{8}$.

La generación permanente de mensajes estimuladores de necesidades y ansiedades materiales es inherente a un sistema social cuya prioridad es la reproducción ampliada del capital. El embellecimiento de estos responde a la necesidad de fomentar la cultura consumista y los medios de difusión masiva son los encargados de pervertir los sentimientos sobre lo que debe tenerse para ser.

Varios estudiosos afirman que el sentido de pertenencia localista se diluye con las ofertas de los emporios del audiovisual y la prensa escrita. Muchos no encuentran respuestas a sus necesidades básicas en la cotidianeidad y ante lo que les llega por estas vías, sienten cada día más empobrecidas los rasgos distintivos que los identifican y quedan al borde de las asfixia, porque no vislumbran cómo enfrentar el desafío.

\section{- $\quad$ Terrorismo mediático}

El novísimo adjetivo en boga sólo alude a una práctica que supera la centuria, desde que William R. Hearst enviara un revelador mensaje a los titubeantes reporteros de su diario (New York Journal) que habían sido designados para cubrir la guerra entre cubanos y españoles, a finales del siglo XIX: "Remington. La Habana. Favor de quedarse. Usted suministre dibujos que la guerra la fabrico yo. W. R. Hearts" .

Desde esa época, numerosos son los ejemplos de la complicidad de los medios con las fuerzas más retrógradas y su predisposición a invadir los espacios ajenos para, a tono con los objetivos de ellas, secuestrar mentes e inducirlas a aceptar el dominio al que se les somete.

Terrorismo es infundir pánico, miedo e inseguridad en individuos o colectivos. Este puede hacerse mediante acciones sistemáticas (1) de naturaleza física y violenta, que afecten a las personas directa o indirectamente, o (2) mediante acciones sicológicas capaces de causar dudas y desasosiego ante la realidad ${ }^{10}$.

En el primero de los casos, los medios son las bombas que ex- 
plotan y matan no sólo al enemigo político sino a los inocentes, las advertencias de explosivos colocados en sitios públicos, los secuestros, asesinatos colectivos, accidentes provocados u otros. El segundo alude a la manipulación de la información, establecida mediante el silencio, la censura, y la propaganda, con la intención de influir en la opinión pública para crear dudas, temores, y zozobras con fines políticos, económicos, religiosos, etc.

Resulta cuestionable relativizar con respecto al terrorismo. Cualquiera que sea su origen o naturaleza, este clasifica entre las peores invenciones humanas. Tarea prioritaria del terrorismo mediático es confundir a los pueblos. Sicológico por naturaleza, este es producto necesario o consecuencia del terrorismo físico, porque o lo antecede o lo precede.

Las enseñanzas de cómo se prepara desde los medios el terreno para justificar una guerra fueron constantes en el último medio siglo. Es incalculable el potencial de la información para arrastrar a un país a un conflicto y la de los medios y agencias publicitarias para usar la verdad, en detrimento de ella misma, y dejar satisfechos a los consumidores con lo que elaboran sin descuidar las reglas del espectáculo. ${ }^{11}$

"El terrorismo mediático es consustancial a las guerras modernas, las calientes y las frías. Esta real invasión, generalmente aparece envuelta en el celofán de una retórica seductora y en los oropeles de un moderno Caballo de Troya. El primero para que los verdaderos propósitos comunicativos pasen inadvertidos, el segundo para deslumbrar y atrapar a los desprevenidos"12.

La guerra mediática es un complemento de las otras guerras, aunque no alcanza a sustituirlas. En todo caso, se suma a las formas tradicionales de represión contra los pueblos y en Latinoamérica, cobra rango de problema de seguridad nacional y regional.

Fernando Buen Abad, comunicólogo mexicano, considera que la envergadura de las campañas mediáticas por desacreditar a los elementos de progreso en este continente debe ser contrarrestada con la instalación de un frente de comunicólogos del área, que en constante intercambio con los movimientos sociales de bases, asuma la problemática como cuestión de dimensiones regionales y articule propuestas de defensa ante esa agresión ${ }^{13}$.

La permanente alerta y el ojo aguzado son imprescindibles ante 
el "totalitarismo" de los medios, que condiciona a los gobernantes a actuar. Los negados a seguir esta corriente, terminan descuartizados o cuando menos tambaleantes ante la opinión pública, luego de recias campañas discriminatorias. Llegar o no al gobierno depende en gran parte de la forma en que se logre una buena imagen a través de la pantalla, los diarios o las webs. La dependencia de los medios guarda relación con los fines electorales y olvidar su incidencia, puede costar caro al mejor de los candidatos ${ }^{14}$.

La satanización de las protestas populares, de sectores sociales, de los líderes de los procesos políticos antiglobalizadores; la deformación de los hechos noticiones a merced de los intereses en juego, el uso y abuso de términos preconcebidos con marcada intencionalidad, y la manipulación de la jerarquía en la escala informativa, son apenas algunos de los rasgos que distinguen a esta manera de concebir la comunicación.

Para sus artífices, son meras trivialidades las masacres étnicas, la muerte diaria de miles de personas por hambre o enfermedades curables en el mundo, o el ametrallamiento de poblaciones enteras bajo cuestionables ideales democráticos. Así vemos como el virus $\mathrm{H} 1 \mathrm{~N} 1$-de proporciones elevadas en su incidencia pero no más pernicioso que la violencia o la desnutrición, que aniquilan a miles de personas por día en el mundo- acapara primeras planas durante meses y lanza a segundos planos las informaciones sobre una de las peores crisis que atraviesa la humanidad.

El terrorismo mediático guarda vínculos estrechos con la tríada periodismo, periodista y poder, y prevalece desde los comienzos de la hostilidad entre la Unión de Repúblicas Socialistas Soviéticas y Estados Unidos por sostener el liderazgo en sus respectivos bloques geopolíticos y controlar políticamente los territorios ultramarinos, ricos en reservas de materias primas y fuentes de energía no renovables.

Ambos bloques hicieron de este un arma común, lo cual explica porqué el tema fue tabú por mucho tiempo. Como señala Gregorio Javier Pérez Almeida, mientras vivíamos preocupados con el peligro nuclear, los países hegemónicos y su contracara soviética convirtieron a la atmosfera en una chivera con cada vez menos ozono, al espacio radioeléctrico en una medusa digitalizada y a la tierra, con su agua y su aire, en un depósito de sustancias venenosas que complican por día la vida humana. Y ahora esta realidad nos explota en la cara...mediáticamente ${ }^{15}$.

\section{- Crisis de credibilidad e insurrecciones mediáticas}

Por suerte, la historia de la comunicación contemporánea muestra el progresivo incremento de la insa- 
tisfacción con este modo de obrar de los medios de difusión masiva. La crisis de credibilidad avanza y algunos hablan de insurrecciones mediáticas ante la creciente "inseguridad informacional"16.

El cuerpo social está desarroIlando mecanismos de alerta ante lo que escucha, lee o ve, en los aparatos ideológicos de la globalización. Baste un recorrido por el espacio virtual y saltarán a la vista las muestras de que la ciudadanía, cercana al convencimiento de que estos la engañan por razones políticas y financieras, les hace la contrapartida.

La articulación de redes contra el proyecto estadounidense de crear un Área de Libre Comercio en las Américas (ALCA), los tratados bilaterales eufemísticamente llamados de libre comercio (TLC) -expandidos ante la frustración inicial del primero ${ }^{17}$, y la hemorragia bloguera contestaría desatada a raíz del golpe de Estado perpetrado contra el presidente constitucional de Honduras, Manuel Zelaya ${ }^{18}$, son apenas algunas de las insurrecciones mediáticas de las que fuimos testigos.

La potenciación del desarrollo en comunicación respondió, desde la invención del teléfono hasta el surgimiento de las redes electrónicas, a las urgencias de los sectores con poder, más las posibilidades creadas en nuestro tiempo hacen imparable el intercambio entre personas de todo el mundo y de las más disímiles ideologías.

Frente a la información oficial difundida por los megamedios, la telefonía celular e Internet, se erigen en este siglo como mecanismos de defensa del derecho a conocer la verdad o al menos, otras visiones sobre un mismo acontecimiento. La cuestionable apertura y participación en los procesos de comunicación se desdobló en un bumerán para sus impulsores.

\section{2-América Latina: propuestas comunicativas por el cambio}

Barrer con los latifundios mediáticos, con el terrorismo implantado por los medios, y democratizar la comunicación y la información, son los eslóganes más repetidos cuando se habla de la necesidad del cambio en ese orden. Todos parecen estar convencidos de tales urgencias, pero cada quien tiene su propia idea de cómo o para qué debe hacerse: las fisuras en este reclamo colectivo son demasiadas, coincidimos con el director del Observatorio Latinoamericano en Comunicación y Democracia, Aram Aharonian ${ }^{19}$. 
Probablemente, un sinnúmero de participantes en tal polémica desconozca el significado real de lo que implica democratizar la comunicación. Más allá de poner los medios en manos del Estado, concebido como representante máximo de la nación, esta debe legitimar el derecho a informar y estar informados, la responsabilidad de los medios de fomentar la formación de la ciudadanía, frenar la articulación y funcionamiento de los monopolios y oligopolios mediáticos, así como garantizar que los medios alienten la recuperación de la memoria y de la cultura nacional.

Las reformas o cambios legislativos en materia de comunicaciones, reclamadas por muchos, supondrían una variación relativa desde el Estado, pero de poco valdrían si ocurrieran sin un previo debate o participación popular eficaz, sin siquiera identificar la problemática y la estrategia a implementar ${ }^{20}$. El desconocimiento de estas cuestiones y de la opinión pública al refrendar una ley de tal alcance puede arrastrar consigo un costo político enorme para cualquier proceso político progresista.

Una normativa pensada desde arriba, sin consultar a los movimientos sociales populares y a la ciudadanía en general, puede terminar siendo autoritaria y restrictiva de la libertad de expresión. Ello implicaría una regresión en los objetivos que deberían orientarla y es casi seguro que los pueblos no podrán perdonarla ${ }^{21}$.

Mientras, las producciones enlatadas de las transnacionales de la información norteñas acaparan la atención de los públicos locales, al ser reproducidas por medios de estos países, y crece el divorcio de generaciones enteras con sus costumbres originales y la asimilación al patrón macdonalizado de pensar y desenvolverse en sociedad.

En tiempos de globalización no basta con la voluntad y la sabiduría popular recuerda que de buenas intenciones, está empedrado el camino al infierno. Es necesario programar modelos de comunicación distintos que acerquen a los desposeídos a los progresos de la ciencia y la técnica, pero no como meros observadores, sino como beneficiarios de sus resultados.

Incluso, aquellos medios que se autoclasifican como alternativos, siguen centrando sus análisis en el accionar de los gobiernos progresistas y poco espacio dedican a visualizar a los únicos capaces de modificar radicalmente las relaciones de fuerza, los movimientos sociales populares o el pueblo en general.

La mentada alternatividad no siempre descansa en bases reales. Terminología, informaciones priorizadas, y formas de presentación, 
suelen ser calcos o acercamientos poco felices a los medios tradicionales y poca relación guardan con los sectores a los cuales dicen representar. Por ello, más cabría denominarlos libres o independientes, o emitidos desde la ciudadanía, como sugiere el comunicólogo Armando Mattelart ${ }^{22}$.

Por suerte, esta no es la regla. Las redes de radios comunitarias son acogidas en su afán por legiti- marse como mecanismos de presión ante las realidades nacionales y comienzan a ser consideradas en sus demandas de cambiar las reglas del sistema de comunicaciones, tendientes a la regulación del sector privado. El acceso y la información son los pilares defendidos por estos medios, que apuestan por la diversidad lingüística, cultural y mediática, en correspondencia con quienes constituyen sus principales receptores: los excluidos o marginados.

"No habrá cambios profundos sin el concurso de los de abajo, organizados en movimientos. Colocar el fondo del análisis en los gobiernos es dejar a un lado nada menos que a la parte decisiva de la realidad, por lo menos desde una mirada antisistémica"23.

Los planes de beneficio popular limitados por su alcance en lo cuantitativo y hasta en lo cualitativo, alivian la situación de los más pobres más no la revierten definitivamente. De cualquier modo, la complacencia momentánea con esa ayuda incide en cierta desmovilización y frena la tendencia a la organización contestaría de los de abajo. Ello sólo conviene a las derechas, todavía con importantes rubros en sus manos como la minería a cielo abierto, los monocultivos de soya y caña de azúcar para biocombustibles, y el complejo forestación- celulosa.

La redistribución de las riquezas es una tarea pendiente en esta América Latina lastimada por las secuelas del neoliberalismo y resulta utópico soñar con cambios de fon- dos sin cumplirla. Por consiguiente, una de las principales causas de los conflictos sociales continúa en pie y puede erigirse en instrumento de movilización contra los progresistas en el gobierno.

El rompimiento con el neoliberalismo sólo será posible a través de una crisis político social. Son demasiado los intereses en juego para esperar lo contrario y las clases medias están plagadas de personas que coquetean con el conservadurismo, por temor a la confrontación y a descender en la escala social, en una época de vaivenes económico. La historia demuestra como puede sobrevenir la derrota por eludir lo inevitable: póngase por caso la rearticulación de la derecha panameña y hondureña, en $2009^{24}$. 
Las derechas latinoamericanas sacaron sus experiencias de errores anteriores y diseñan sus estrategias para recuperar el terreno perdido en las esferas gubernamentales, sacudir a los elementos molestos para afianzar su poder y avanzar hacia el aniquilamiento de sus peores enemigos: los movimientos sociales populares.

La democracia sólo se salvará en América Latina y el Caribe si se logra democratizar los medios, pero para ello resulta indispensable una remoción radical de los pilares básicos sobre los cuales se sustenta el dominio capitalista, y así allí deben dirigirse las miradas sin vacilación, más convocando el concurso de todos.

Para José Martí, el problema de la independencia en Latinoamérica no era el cambio de formas, sino de espíritu y transcurridos dos siglos de la independencia política, queda por hacer para acabar con el vasaIlaje en el plano del pensamiento ${ }^{25}$. Incalculable resulta el valor del patrimonio cultural y natural diseminado del Río Bravo a la Patagonia, pero no siempre somos capaces de reconocerlo y apelamos a fórmulas trasplantadas para solucionar nuestros problemas.

En cuanto a las comunicaciones, múltiples son las contribuciones de los de estas tierras -tanto en el orden teórico como práctico- y la recuperación de esas aportacio- nes -entre las que destaca por su singularidad la preocupación por la transformación política y socialpuede servir a la conformación de una teoría de la comunicación antihegemónica y de manera particular, a la batalla por contrarrestar la dictadura mediática prevaleciente en este siglo.

Es importante no perder de vista el necesario cambio de paradigmas en esta guerra cultural, en la que sucumbiremos si nos aferramos sólo a consignas, en vez de prepararnos adecuadamente en el dominio y manejo de las tecnologías y de otros resultados científicos. Por las venas de un amplio grupo circula que prensa alternativa significa comunicación marginal y hoy queda claro que la única forma de adelantar en la cruzada de ideas que se nos hace es con una estrategia comunicacional masiva, realmente alternativa al sistemático bombardeo mediático proveniente del Norte.

\section{- Mujeres: potenciadoras del cambio en Comunicación}

Cuando las mujeres comenzaron a romper con la costumbre que las mantenía confinadas al rincón doméstico, impulsaron una rebelión que las colocó poco a poco en el espacio público local e internacional. Sobre todo en los movimientos sociales populares, estas han ido construyendo espacios para repensar el mundo y articular acciones. 
Sally Burch, directora ejecutiva de la Agencia Latinoamericana de Información, atribuye al movimiento de mujeres el mérito de intuir primero que los ufanados en transformar el status quo, podrían servirse de los medios de difusión masiva para empoderarse y avanzar en sus luchas ${ }^{26}$.

En la Conferencia de Beijing, en 1995, representantes de las mujeres de casi todo el planeta criticaron la falta de democracia en el manejo y distribución de los beneficios de las Tecnologías de la Información y la Comunicación (TIC) e instaron a contemplar como un derecho de todas y todos el acceso a las mismas, la formación para su uso, y la participación en las decisiones sobre su desarrollo y empleo.

Las feministas habían identificado desde mucho antes la ligazón entre difusión mediática y perpetuación de valores y actitudes discriminatorias. En contraposición a ello, incluyeron en sus programas el enfrentamiento a las imágenes negativas y estereotipadas de las mujeres en los medios y en la publicidad, a su invisibilización en tanto actoras de opinión o agentes de cambio, al lenguaje sexista y a la discriminación contra las profesionales de la comunicación.

De igual modo, las mujeres promovieron las iniciativas de media literacy o alfabetización en lectura de los medios ${ }^{27}$, destinadas a propulsar desde la niñez una actitud crítica de cara a los mensajes comunicativos emitidos por estos y contrarrestar así los efectos de la dictadura del Segundo Poder.

Foros por Internet, medios alternativos feministas, radios comunitarias, conferencias de organismos regionales e internacionales, acciones contra la publicidad sexista y marginadora, fueron algunos de los espacios donde las mujeres compartieron con otros grupos sociales sus experiencias en el enfrentamiento al modelo de comunicación predominante y articularon programas para democratizar esta, con un enfoque de género.

La Minga Informativa de Movimientos Sociales, iniciativa de convergencia en comunicación entre agrupaciones populares de América Latina y el Caribe, es uno de los medios que desde la ciudadanía incentivó la capacitación en género y comunicación de las mujeres y líderes de organizaciones sociales del continente. Un espacio dedicado a estos asuntos mantiene al día a los que reciben el servicio y visualiza las fronteras por rebasar hacia la emancipación total de las féminas.

Estas acciones encontraron eco en otros movimientos emergentes, como los de las minorías étnicas, campesinos, gay y lesbianas, cuyos líderes comprendieron la necesidad de construir la resistencia frente a la discursiva del aparato mediático 
y para concientizar a la ciudadanía de los derechos de esos sectores a ser sujetos activos de comunicación y no meros espectadores y receptores de mensajes.

\section{- Pedagogía popular desde los movimientos sociales populares}

Los movimientos sociales populares en América Latina nacieron de la emergencia de nuevos actores, agrupados por oposición al terremoto social que provocó la oleada neoliberal. La imposición de las políticas atravesadas por la lógica del mercado, en detrimento de los seres humanos y de la naturaleza, recrudeció la rutinaria situación de los marginados y en consecuencia, estos crearon nuevas vías para exteriorizar sus demandas.

En consonancia con el profesor de la Multiversidad Franciscana de América Latina, Rául Zibechi ${ }^{28}$, tres son las corrientes político- sociales que forjaron la armazón ético y cultural de los movimientos más significativos en el área: las Comunidades Eclesiales de Base vinculadas a la Teología de la Liberación, la insurgencia indígena portadora de una cosmovisión distinta de la occidental y el guevarismo, inspirador de una militancia relacionada con el símbolo que supone para muchos de los interesados en el cambio social el ejemplo de Ernesto Guevara.
El entrecruzamiento entre estas tendencias de pensamientos y acción es otra expresión del mestizaje característico de este continente híbrido y suele ser reconocido como un sello peculiar de los movimientos sociales populares latinoamericanos, similares por la territorialización o arraigo a espacios físicos recuperados mediante luchas abiertas o subterráneas, la búsqueda de una autonomía de los Estados y de los partidos políticos, y de la revalorización de la cultura y la afirmación de su identidad.

En igual sentido puede distinguirse la capacidad de generar desde su seno intelectuales o personas con conocimientos, capaces de impulsar la auto-organización y la auto-formación de sus dirigentes, con criterios pedagógicos propios, ligados a la educación popular. El paulatino ascenso del protagonismo femenino constituye aspecto coincidente en estas agrupaciones, como expresión del nuevo tipo de relaciones establecidas entre mujeres y hombres al interior de las mismas y en los territorios donde operan. Igual, la preocupación por la organización del trabajo y el vínculo de los seres humanos con la naturaleza, a tono con patrones legados por las culturas ancestrales.

Los movimientos sociales populares latinoamericanos procuran alejarse de la organización taylorista o jerarquizada -con divisiones 
de tareas entre quienes dirigen $y$ ejecutan- y lograr una vinculación más efectiva entre los dirigentes y las bases. Estas organizaciones marchan a la cabeza de las transformaciones en algunas naciones latinoamericanas, pero en igual proporción deberán exorcizar el temor a perder su autonomía y a vivir en una negociación continua con el Estado. También tendrán que diseñar formas más atractivas para atraer a los jóvenes en medio de la macdonalización del pensamiento y defender su independencia relativa, sin renunciar a la necesidad de articular alianzas con otros grupos, clave para el triunfo frente al capital y sus complejas redes.

Es en el campo de la comunicación donde la lucha por afianzarse resulta más álgida. La radio, la televisión, el teléfono celular, el correo electrónico, los chats, y otros soportes de Internet, son los canales por excelencia para alcanzar el reconocimiento que legitima la existencia de las redes sociales y atraer a los más jóvenes ${ }^{29}$.

Con el objetivo de hacer un mejor uso de estos canales y alcanzar estos fienes, los movimientos sociales populares han creado herramientas, códigos, símbolos, lenguajes y señales, en las cuales subyace una pedagogía popular que concibe a la comunicación como elemento fundante de la praxis transformadora ${ }^{30}$.
La pedagogía popular de la comunicación o pedagogía del ejemplo, según los Sin Tierra del Brasil, hace de la comunicación interpersonal en el seno de los movimientos, entre los distintos movimientos, y de estos con el resto de la sociedad, dimensiones concretas que requieren ser trabajadas como parte de la batalla cultural antihegemónica.

Las palabras recuperan el valor de los actos en esta estrategia elaborada fuera de la academia, en tanto señalan, adivinan y pelean sentidos, que atraviesan históricas incomprensiones. Ellas fungen como mediadoras de una comunicación que fluye en prácticas sociales colectivas, comunitarias, y develan lo ocultado tradicionalmente por los medios.

Esta propuesta es una suerte de espejo donde se pueden apreciar múltiples miradas simultáneas de mujeres y hombres de diversas extracciones sociales y vivencias, sin privilegiar unas sobre otras y haciendo de las diferencias el punto de partida para posibles encuentros.

Construir sujetos colectivos con capacidad de transformación, requiere de una comunicación favorecedora de la identificación de los distintos actores sociales, la comprensión de los contrastes entre ellos y sus fundamentos, la capacidad de discriminar lo diferente y lo 
antagónico, y la creatividad para tejer los fragmentos de un discurso roto y de un lenguaje mutilado por la dictadura mediática del pensamiento único. En la pedagogía popular de la comunicación, el diálogo y la pregunta aparecen como momentos esenciales. La pregunta y la escucha son tan reverenciadas en esta modalidad como la respuesta y la opinión.

Frente al desafío de comunicar y comunicarnos, este accionar dice de la manera de entender la militancia en estos tiempos y el comprometimiento de sus artífices con el cambio social. Ellos promueven la lucha cultural, al mismo tiempo que revalorizan en el imaginario popular la aceptación de las posibilidades de transformar la sociedad y sientan las bases para la formación de intelectuales orgánicos de extracción popular.

Entre las herramientas apropiadas por los movimientos sociales para comunicar sus aspiraciones están los sitios electrónicos, multimedias, mensajes televisivos elaborados por los movimientos, radios comunitarias, videos, graffitis callejeros, libros, marchas y actos que comunican, performance, redes de información alternativa, agencias de comunicación, representaciones teatrales, murgas, y otras expresiones de arte popular.

Las claves comunicacionales predominantes en los mensajes emi- tidos por estas vías son autóctonas y recrean el imaginario popular desde la probabilidad de revolucionar el mundo sin renunciar a la influencia de anteriores modalidades de resistencia.

Múltiples son los espacios ganados en la última década, pero mucho queda por hacer. Para Joel Suárez Rodés, Coordinador General del Centro Martin Luther King Jr., los movimientos sociales populares desempeñan un rol importante en el contexto regional pero deben viabilizar la preparación de sus miembros en el orden político, con una visión más integradora ${ }^{31}$.

La dispersión, el aislamiento y la espontaneidad, golpean a algunas de estas iniciativas y limitan su capacidad de impacto de cara a un panorama que evoluciona por segundos. Ello devela la necesidad de tomar en cuenta también los resultados de la elaboración científica, particularmente en el plano comunicológico.

\section{- Crear: palabra de orden en comunicación en Latinoamérica}

El devenir de la lucha contra la globalización y la dictadura ejercida por los medios de difusión masiva descubre la relevancia de sistematizar las propuestas interdisciplinarias de las ciencias sociales y en particular, en comunicología, para el diagnóstico preciso y el de- 
sarrollo de un estrategia dirigida a la articulación de una Comunicación Social Antihegemónico u orientada al socialismo.

La incidencia de los enfoques de la dependencia condujo a los estudiosos de esta disciplina en la región, desde los años sesenta del siglo pasado, a buscar cierta identificación y unidad entre ellos, particularmente, entorno a la producción ética- epistemológica. Innegable resulta su vínculo con el denominado pensamiento decolonial o proyecto decolonial, de la modernidad/colonialidad o teoría postoccidental, inusitada expresión de la teoría crítica ligada a las tradiciones de las ciencias sociales en la zona.

Este pensamiento se articula desde el subcontinente, pero no se circunscribe a él. Más bien, retoma de modo crítico y dialoga con otros proyectos intelectuales y políticos autóctonos y de otras partes del mundo, y en sintonía deviene novedosa alternativa para reflexionar acerca del sentido de pensar desde la especificidad histórica y política de nuestras sociedades tercermundistas. En igual sentido, refuerza su interconexión con propuestas medulares de la trayectoria intelectual latinoamericana y caribeña, como los debates sobre el colonialismo, la Filosofía de la Liberación, la Pedagogía Crítica y la Teoría de la Dependencia, entre otras.
Las alternativas que plantea a los principios de comprensión de la historia, de las jerarquías naturalizadas de los conocimientos, de los silenciamientos constitutivos de las narrativas y tecnologías de intervención modernas, de las corporalidades y subjetividades, arrojan luz acerca de su profundo poder de crítica frente a los paradigmas dominantes.

Este proyecto constituye una perspectiva analítica para comprender de otra manera algunas de las problemáticas que enfrentan estas naciones frente a la globalización neoliberal, como la distribución y recepción de conocimientos en las ciencias sociales, las articulaciones de los imaginarios y diversas acciones que trascienden las formaciones nacionales.

La búsqueda de la identidad latinoamericana en esta esfera del saber tiene un largo camino por recorrer hasta llegar a su conformación, más pueden ubicarse algunos puntos de partida en el análisis de los debates dominantes sobre el tema. Entre ellos cabe mencionar las tesis sobre la relevancia social del objeto de estudio en la investigación, la invocación a cuestionarnos qué problemas necesitan ser investigados y cuáles preguntas debemos hacernos y respondernos en nuestros países; hasta qué punto y desde dónde están siendo renovadas o reconfiguradas las utopías fundacionales 
de estos estudios en las diferentes etapas y los momentos de desarrollo del campo; y cuestiones de ese tipo insuficientemente debatidas por los investigadores latinoamericanos de la comunicación ${ }^{32}$.

El quehacer por la identidad desde la comunicología se refleja en la polémica alrededor de la existencia, peculiaridades y caminos a seguir en la intención de crear un modelo ideal en la zona, al cual poder identificar sin riesgos Escuela Latinoamericana de Comunicación $(\text { ELACOM })^{33}$. José Marques de Melo, Guillermo Orozco y Martín Barbero, lideran este movimiento.

En el anhelo de romper con el vasallaje cultural en estos términos se gestaron otras valiosas aportaciones autóctonas a la producción teórica en la rama. Entre estas despuntan el reconocimiento de los grupos sociales como sujetos de la historia; el pensar la comunicación como escenario social, donde logra superarse la denominación técnica y tecnológica, y concebir esta como "mediación", "proceso", "interacción", "intercambio de sentidos", "inter- aprendizaje".

La originalidad y especificidad de la investigación latinoamericana en comunicación derivó de una evolución social concreta. Ello explica en cierta medida su cantidad y madurez, reflejados en múltiples libros publicados -sobre temas que van de la semiótica a la comunica- ción popular-; la existencia de casi una decena de revistas especializadas -que difunden artículos de trascendencia teórica elaborados en estos países y gozan de amplia distribución-; en el accionar de decenas de facultades e institutos, programas de investigación en comunicación, y en el diseño y de algunas políticas de comunicación estatales.

Pese al debate que rodea a la ELACOM, esta distingue por una notable intercomunicación entre los investigadores, los proyectos de investigación cooperativa y la conexión entre diversas organizaciones, institutos, publicaciones y facultades. También, por su relación directa con la formulación de la política de medios de comunicación, con los esfuerzos para formarlos $y$, especialmente, con los movimientos sociales populares que introducen formas alternativas de comunicación y de medios y su preocupación por el cambio político y social ${ }^{34}$.

De la reflexión teórica latinoamericana, los investigadores cubanos suelen reconocer ${ }^{35}$ la comprensión del proceso de recepción a partir del contexto en el cual se desarrollan las prácticas de lectura y consumo; el rescate del papel esencial de los actores sociales concretos en esa producción e intercambio de sentidos; el compromiso con la realidad social y el respeto a los involucrados; la visualización de la problemática de la hegemonía como cuestión central 
para entender la comunicación y los procesos de recepción y consumo, entre otros.

Talón de Aquiles en los esfuerzos de los latinoamericanos por cambiar el mundo, desde el siglo pasado, es la supervivencia del eurocentrismo, el iluminismo, y el positivismo, corrientes que reforzaron la base cultural colonizada del pensamiento dominante en la izquierda y en amplios sectores académicos de la región. Ello distanció a estos estamentos y sus resultados científicos de las culturas de resistencia de los pueblos originarios y en algunos lugares, este desencuentro reforzó el aislamiento de las batallas de estos pueblos, sus esfuerzos de resistencia silenciosa al etnocidio, empobreciendo al pensamiento crítico.

Esta es una de las primeras barreras por romper en el necesario acercamiento entre mujeres y hombres de ciencia a los movimientos sociales populares en estos tiempos y a las experiencias de estos en materia comunicativa. La liberación implica voluntad y poder. La creación de una cultura crítica coincide con la conformación del poder de los pueblos y en ese sentido, hay mucho por cambiar.

El saber universitario no debe mantenerse arrinconado en ese espacio sino salirse, porque la sociedad necesita del saber elaborado en las facultades de ciencias de la comunicación para responder a las interrogantes de los ciudadanos. Más intelectuales, en alianza con los movimientos sociales populares, deben sumarse a ese doble papel de estudiosos y agitadores políticos, mediáticos, y pasar a la denuncia de los medios que mienten y a la protesta popular ${ }^{36}$.

La expropiación de medios privados, la suspensión de concesiones, la apertura de nuevos canales comunicativos, deben estar acompañados de un sentido de unidad inexcusable para producir imágenes e imaginarios hacia el socialismo y librarse de estigmas como el individualismo, el empirismo, de la volatilización del negocio de secta disfrazado de progresismo.

Buen Abad propone impulsar una corriente internacional de la comunicación hacia el socialismo con movimientos sociales populares de base, asegurar la independencia política, semántica y sintáctica, con una programación abierta y planificada sobre una agenda temática internacional que satisfaga las necesidades de la construcción social bajo los preceptos socialistas; crear una red permanente de denuncia para las fuerzas naturales y laborales productoras de riquezas; y estimular la movilización de usuarios e interlocutores críticos, capaces de perfeccionar la comunicación nueva, hecha esta vez por toda y todos ${ }^{37}$.

En este proyecto lo más definido es lo que se pretende: democra- 
tizar las herramientas tecnológicas, renovar su uso con ideas y lenguajes revolucionarios, en un escenario de lucha de clases, y contra el rol de las empresas privadas que las emplean como armas de la guerra ideológica. Al unísono, constituye urgencia extirpar en comunicación: lo que la amordaza y abate en la vorágine simbólica decadente, en las vulgaridades, el despojo y la obscenidad; la desinformación, la ignorancia, el intermediarismo, la prostitución, el alcoholismo, la narco-dependencia y el machismo; los racismos, autoritarismos, paternalismos, la demagogia, el dogmatismo, la charlatanería; la represión, la violencia y las guerras; la censura, la explotación, la doble moral, la hipocresía, la traición, la depresión, la atomización, el desánimo y la infelicidad.

\section{Notas}

1. Ponencia presentada al VII Taller Internacional Sobre Paradigmas Emancipatorio.Instituto de Filosofía, La Habana, 2 al 5 de septiembre de 2009

2. Galeano, Eduardo. (2008) Nuestra región es el reino de las paradojas. Palabras de agradecimiento a los representantes del Mercado Común del Sur por el título de Primer Ciudadano Ilustre de la región. Notas acopiadas por la autora durante la transmisión televisiva del homenaje.

3. Rojas Andradae.Alberto. (2008) Vigencia de la propaganda fascista. Rebelión, España, 25 de julio de
En este mundo mediático, se impone actuar por una revolución radical y el uso de Internet con imaginación y sentido de la creatividad, es imprescindible para reinventar el periodismo en correspondencia con los tiempos que corren. Hay que probar en la práctica la capacidad de unidad y respuesta inmediata a lo que acontece. Se trata de actuar organizados con disciplina de combatientes comunicacionales por una comunicación democrática, porque a fin de cuentas, tenemos el plan de las oligarquías al frente, conocemos sus orígenes y sus fines, y sabemos que sólo nos toca superar los atrasos y limitaciones a partir de la sincronización de las agendas de todas y todos los interesados en quebrar este estado de hecho.

2008. Disponible en: www.rebelión. org/noticia.php?id =7

4. Recurrimos al eufemismo Medios de Difusión Masiva y no a Medios de Comunicación Masiva, por cuanto la mayoría de estos apenas transmiten, difunden, e imponen, supuestas verdades de acuerdo con su posición de aparatos ideológicos de la globalización.

5. Ramonet, Ignacio. (2007) Los medios son el aparato ideológico de la globalización. Conferencia en la clausura de la Bienal Iberoamericana de Comunicación, Córdoba, Argentina. Disponible en: www.rebelion. org/noticia.php?id=S 
6. Recuerdese que este concepto surge ligado a ideas básicas de la ilustración francesa. Montesquieu, en El espíritu de las leyes, catequizó que para que la sociedad funcionara de modo armónico y pudiera autogobernarse, precisaba de tres poderes: uno representativo de todas los actores sociales, encargado de elaborar las leyes para organizar el entramado social; otro responsable de hacer cumplir estas para preservar la democracia o la República; y otro con la misión de castigar a quienes violasen las mismas, sin distinción. El desarrollo de los MDM, en vísperas de la Primera Guerra Mundial (1914-1918), favoreció el surgimiento de lo identificado como Opinión Pública. El apego de esta a las supuestas verdades emitidas por los medios y su movilización en sintonía con ello, relativizó la legalidad de los tres poderes originarios en la democracia e hizo suponer la existencia de un Cuarto Poder: los MCM.

7. Korol, Claudia. (2007). La pedagogía popular de la comunicación. Rebelión, España, 8 de noviembre de 2007. Disponible en: http://www. rebelión.org/noticias.php?id $=5$

8. Korol, Claudia. (2007). La pedagogía popular de la comunicación. Idént.

9. Timoteo Álvarez, Jesús. (1988). Historia y modelos de comunicación en el siglo XX. Círculo de Lectores, Barcelona, 1988. Reproducción de la Editorial Pablo de la Torriente Brau, La Habana, 2008. p.71.

Historiadores concuerdan en que la la primera guerra imperialista de la historia -la hispano- cubanaestadounidense-filipina de 1898-,fue, esencialmente, obra de Hearst y de la prensa amarillista, sin desconocer la predisposición estadounidense de creerse designado a evangelizar en cuanto a democracia al mundo y particularmente, al resto de América. La campaña alrededor del caso de Evangelina Cisneros -apresada por colaborar con los independentistas y convertida por esta prensa en víctima, bajo la mentira de que era hija de un líder revolucionario cubano encarcelado y estaba acosada por un libidinoso coronel español-, las supuestas críticas del embajador de ese país europeo en Washington, Dupuy de Lome, al presidente MacKinley, la satanización de los soldados españoles, y el montaje sobre el hundimiento del buque Maine, condimentaron la sopa de odio suministrada a grandes buches a los norteamericanos y provocaron el esperado respaldo a la intervención norteña en el conflicto hispano- cubano.

10. Pérez Almeida, Gregorio Javier (2008) Hiroshima: la noticia que nunca fue. A plena voz, Edición No. 41, abril de 2008, Caracas, p. 12

11. Serrano, Pascual y Alba, Santiago. (2008). A plena voz, Edición No. 41, abril de 2008, Caracas, pp. 7-9. Los autores recuerdan Vender la guerra, documental de la productora The Fitftn State, de la cadena canadiense $\mathrm{CBC}$, que develó el montaje sobre el supuesto secuestro y asesinato de 312 bebés kuwaitíes por soldados iraquíes, cuando los se- 
gundos invadieron el primer país, en 1991. El hecho devino pretexto de la intervención militar estadounidense en Iraq, en marzo de 2003. Igual, este puso al descubierto el papel desempeñado por la mayor empresa publicitaria de América del Norte, a Hill\&Nnowlton.

12. Pérez Betancourt, Roberto (2004) Terrorismo mediático. Agencia de Información Nacional, La Habana, 2 de septiembre de 2004. Disponible en:

http://www.ain.cu/patriotas/ sep0402cbterrorismo.htm

13. Buen Abad, Fernando. (2008) Entrevista concedida al equipo de redacción de A plena voz, Edición No. 41, abril de 2008, Caracas, pp. 10-11.

14. Prueba al canto: la suciedad con que los principales medios salvadoreños secundaron a la Alianza Republicana Nacionalista y a su candidato Elias Antonio Saca, con tal de evitar $-\mathrm{y}$ consiguieron- la victoria previsible del líder histórico del Frente Farabundo Martí para la Liberación Nacional, Schafik Handal, en las elecciones de 2004.

15. Pérez Almeida, Gregorio Javier (2008) Hiroshima: la noticia que nunca fue. Idént. p. 13

16. Ramonet, Ignacio. (2007) Los medios son el aparato ideológico de la globalización. Idént.

17. Frustración inicial porque, a la larga, el establecimiento de los TLC propició el cumplimiento parcial del programa hegemónico norteamericano y sentó las pautas para el progreso del control del comercio de bienes y servicios en la región. Al respecto: Soto Mayedo, Isabel. (2006). ALCA ¿un proyecto aplazado? Rebelión, España, 18 de abril de 2006. Disponible en: http://www.rebelion.org/ noticia.php? $\mathrm{id}=30114$

18. Mientras los medios distorsionan el acontecer en el país centroamericano, sometido a estado de sitio, los sectores populares siguen rompiendo con la mudez ante sus acciones de resistencia a través de varios sitios web cuestionadores e impulsan una red de intercambios de información sobre la represión desatada en el país centroamericano.

19. Aharonian, Aram. (2009) Democratizar las comunicaciones sí, pero... ¿sabemos cómo y para qué? Agencia Latinoamericana de Información, Quito, 25 de agosto de 2009. Disponible en: http://alainet.org/active/32620

20. Aharonian, Aram. (2009) Democratizar las comunicaciones sí, pero... ¿sabemos cómo y para qué? Idént.

21. La Ley venezolana de Telecomunicaciones es considerada como las más neoliberal de América Latina. Esta ley madre debe ser revisada previo al repaso de la Ley de Responsabilidad Social de Radio y TV (alias Resorte), con los reglamentos que impiden la difusión libre y en igualdad de condiciones de las radios y televisoras comunitarias. En el caso venezolano, considera Aharonian, es procedente y necesario democratizar el uso de ese bien público, mediante una reingeniería de frecuencias y licencias, que permita una distribución equitativa entre el sector estatal, el 




22. Mattelart, Armand. (2008) No puede haber diversidad cultural sin diversidad mediática. Entrevista concebida a Pujols, Yoana. La Jiribilla, La Habana, 14 de febrero de 2006.

23. Zibechi, Raúl. (2009) Progresismo y liberalismo. Con Nuestra América, San José, Costa Rica, julio de 2009. Disponible en:

http//:/conuestraamerica.blogspost. com/2009/07/progresismo-y-neol

24. La cautela en las medidas de beneficio popular adoptadas por ambos gobiernos, salvando las distancias, conllevaron a que los desposeídos permanecieran en condiciones de vulnerabilidad frente a las campañas mediáticas y a los manejos de la derecha, que finalmente logró derrotar en elecciones al presidente panameño Martín Torrijos y sacar del país a su par hondureño, Zelaya.

25. Aquí aludimos al vasallaje cultural o a la supeditación en el plano de las ideas a los patrones eurocéntricos legados a los pueblos de las antiguas colonias por sus otroras metrópolis y transmitidos de generación en generación durante siglos. Implica la asunción acrítica de las concepciones originadas en los centros de poder y la subestimación de las potencialidades creativas de mujeres y hombres de las naciones menos favorecidas por esta historia.

26. Burch, Sally. Comunicación: nuevo eje de resistencia. Agencia Latinoamericana de Información, Quito, .Disponible en: http://alainet.org/ active $/ 167=$ es

27. La propuesta de alfabetizar a la ciudadanía en el estudio de los medios, con el fin de dotarla de herramientas necesarias para la lectura crítica de estos es atribuida al teórico de la comunicación Roger Silverstone.

28. Soto Mayedo, Isabel. Movimientos sociales en América Latina: caminos por recorrer. Idént.

29. Martell, Lenin. (2006) Movimientos sociales en América Latina y medios de comunicación ante la encrucijada del neoliberalismo. Razón y palabra, México, No. 51 de 2006. Disponible en: http//www.razonypalabra.org. $\mathrm{mx} /$ anteriores/n51/lmartell.html

30. Korol, Claudia. La pedagogía popular de la comunicación. Idént.

31. Soto Mayedo, Isabel. Movimientos sociales en América Latina: caminos por recorrer. Agencia Boliviana de Información, La Paz, 25 de abril de 2009. Disponible en:

ht tp://www.abi.bo/index. php? i = internacionales_ texto\&j=20090422102446

32. León, Gustavo A. (2008) ELACOM: referente histórico y conquista de la hegemonía en el pensamiento latinoamericano de la comunicación. Razón y Palabra No. 61 de 2008, México. 
33. Concepto sujeto a polémica como la existencia misma de esta. Su gestación guarda relación con el impulso recibido por los estudios comunicológicos, a partir de los años setenta del siglo veinte. Distinguió por el mestizaje teórico, el hibridismo metodológico, el compromiso ético político y la dimensión extranacional, por oposición a sus predecesoras europeas o estadounidenses, plagadas de homogeneidades. La obra de los principales exponentes de la ELACOM -entre los cuales pueden señalarse intelectuales oriundos de la región y extranjeros asentados en ella- expresa la búsqueda de la identidad latinoamericana en materia comunicológica y la sistematización de sus aportaciones puede redundar en su conversión en un paradigma dominante en los estudios de la materia, sin desconocer a aquellas de las cuales se nutrió. Entre sus precursores destacan Luis Ramiro
Beltrán, Guillermo Orozco, Jesús Martín Barbero, José Marques de Melo, y otros.

34. White, Robert A. (1989) La Teoría dela Comunicación en América Latina: Una visión europea de sus contribuciones. Revista Telos, Núm. 19. FUNDESCO, Madrid.

35. Alonso Alonso, María Margarita. La investigación de la comunicación en Cuba: Préstamos teóricos para un itinerario singular. Facultad de Comunicación de la Universidad de La Habana. Notas de clase.

36. Ramonet, Ignacio. (2007) Los medios son el aparato ideológico de la globalización. Idént.

37. Buen Abad, Fernando. (2007) No hay alternativa: es preciso ganar la batalla simbólica. Jornada Internacional El derecho ciudadano a informar y estar informado, Caracas, 18 al 20 de mayo de 2007. Rebelión, España. Disponible en: http://www. rebelion.org/noticia.php/?id=5 